\title{
3D NUMERICAL MODELLING OF THE SEISMIC RESPONSE OF THE THESSALONIKI URBAN AREA: THE CASE OF THE 1978 VOLVI EARTHQUAKE
}

\author{
Smerzini C. ${ }^{1}$, Pitilakis K. ${ }^{1}$ and Hashemi K. ${ }^{2}$ \\ ${ }^{1}$ Department of Civil Engineering, Aristotle University of Thessaloniki, Thessaloniki, Greece, \\ chiara.smerzini@gmail.com,kpitilak@civil.auth.gr \\ ${ }^{2}$ Department of Civil and Environmental Engineering, Politecnico di Milano, Milan, Italy, \\ seyedehkiana.hashemydahaj@polimi.it
}

\begin{abstract}
This study aims at showing the numerical modelling of earthquake ground motion in the Thessaloniki urban area, using a 3D spectral element approach. The availability of detailed geotechnical/geophysical data together with the seismological information regarding the relevant fault sources allowed us to construct a large-scale $3 D$ numerical model suitable for generating physics-based ground shaking scenarios within the city of Thessaloniki up to maximum frequencies of about $2 \mathrm{~Hz}$. Results of the numerical simulation of the destructive $M_{W} 6.51978$ Volvi earthquake are addressed, showing that realistic estimates can be obtained. Shaking maps in terms of ground motion parameters such as PGV are used to discuss the main seismic wave propagation effects at a wide scale.

Keywords: deterministic seismic hazard, seismic wave propagation, Spectral Element Method.
\end{abstract}

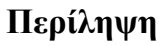

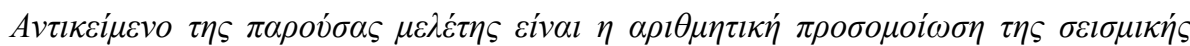

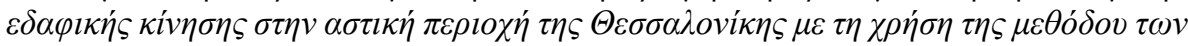

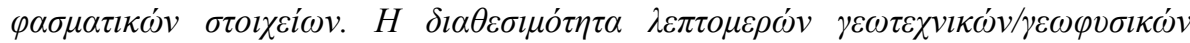

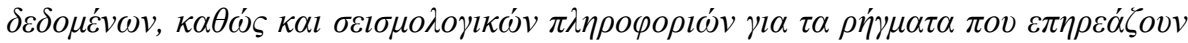

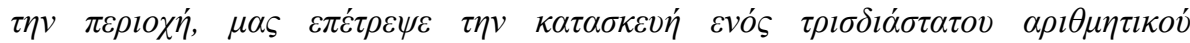

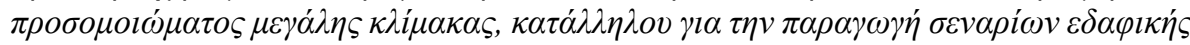

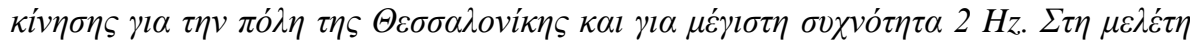
$\alpha v \tau \dot{\eta} \quad \pi \alpha \rho o v \sigma i \alpha ́ \zeta o v \tau \alpha l \quad \alpha \pi o \tau \varepsilon \lambda \dot{\varepsilon} \sigma \mu \alpha \tau \alpha \quad \tau \eta \varsigma \quad \alpha \rho \imath \theta \mu \eta \imath \kappa \dot{\varsigma} \varsigma \quad \pi \rho o \sigma o \mu о i \omega \sigma \eta \varsigma \quad \tau o v$

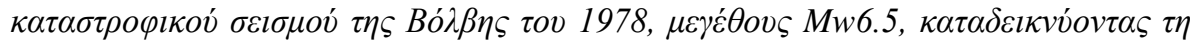

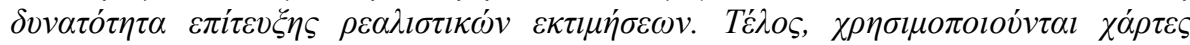

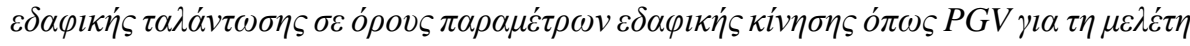

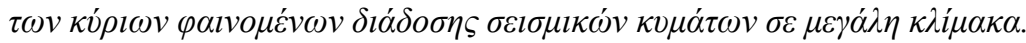

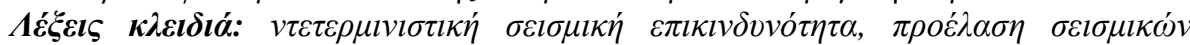

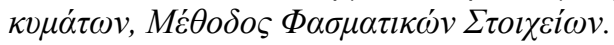




\section{Introduction}

Thessaloniki, the second largest city in Greece after Athens, is located in the Axios-Vardar zone, which is adjacent to the Servomacedonian massif (see Figure 1), extending from the YugoslaviaBulgaria border up to the North Aegean Trough. The Servomacedonian massif is one of the most seismotectonically active zone in Europe; a large portion of its seismicity is associated to the Mygdonia graben, around $25 \mathrm{~km}$ northeast of Thessaloniki, where on 20 June 1978 a destructive earthquake with moment magnitude $\mathrm{M}_{\mathrm{W}} 6.5$ occurred. The 1978 earthquake caused extensive damage to many villages located close to the epicentral area (Stivos, Scholari, Peristeronas, Gerakarou), as well as in Thessaloniki, where the death toll reached the value of 45 people. It is considered as the first earthquake with a serious impact on a big modern urban centre in Greece.

The earthquake attracted the attention of many researchers and marked the beginning of several studies, extending from the analysis of the seismological features of the largest events as well as of the aftershocks of the seismic sequence (see thorough overview in Roumelioti et al., 2007), to microzonation studies and researches related to the quantification of the local site effects (e.g., Lachet et al., 1996; Triantafyllidis et al., 2004a, b; Raptakis et al., 2004a,b), up to the construction of a 3D geotechnical/geophysical model for the sedimentary and bedrock formations within the city of Thessaloniki (Anastasiadis et al., 2001; Apostolidis et al., 2004).

The aim of this study is to present a numerical study on the prediction of earthquake ground motions in the Thessaloniki urban area, based on a full 3D model both of the seismic fault rupture and of the source-to-site propagation path, with reference, in particular, to the $M_{W} 6.51978$ earthquake. Numerical simulations were carried out using a high-performance code, namely SPEED, based on the Discontinuous Galerkin Spectral Elements Method (DGSEM). The comparison between synthetics and observations at the only available strong motion station will be addressed together with the comparison with Ground Motion Prediction Equations (GMPEs) and the generation of ground shaking maps at a broad scale.

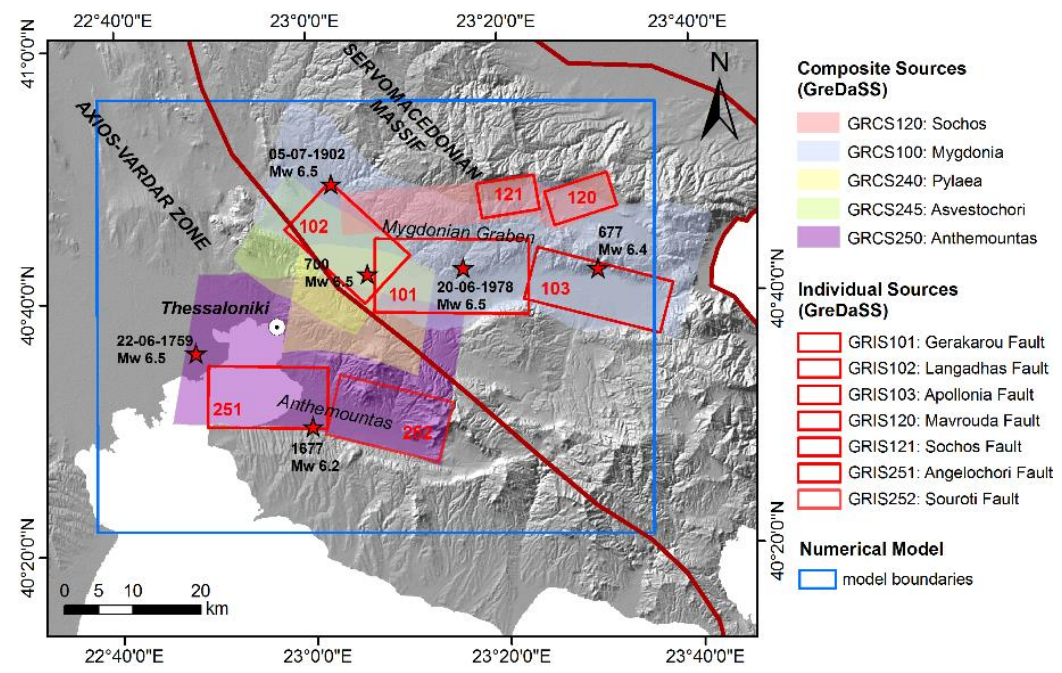

Figure 1 - Seismic sources for the broader Thessaloniki area, as provided by the GreDASS database, and distribution of the epicentres (denoted by the stars) of the historical earthquakes with $\mathrm{Mw}_{\mathrm{w}}>6$. The blue box indicates the extent of the 3D model.

\section{Seismotectonic and Geologic Context}

The broader Thessaloniki area lies in Central Macedonia, an area characterised by extensive NWSE and E-W-trending continental-type basins and grabens, filled with Neogene and Quaternary 
sediments, which formed as a result of Miocene to present extensive brittle extensional deformation that mainly related to high-angle normal faults (Tranos et al., 2003). Among them, the Mygdonian graben is the largest basin in the area (see Figure 1) and its continuous seismic activity poses a serious threat to the city of Thessaloniki. The tectonic regime of the broader area is characterised by extensional deformation associated mostly with E-W, NW-SE or NE-SW striking faults (Tranos et al., 2003; Paradisopoulou et al., 2006). The E-W trending faults are mainly normal dip-slip, while the NW-SE and ENE-WSW ones occasionally show strike-slip components of movement. The fault system bounding the southern boundaries of the Mygdonia graben (Gerakarou fault) was responsible of the destructive 20 June 1978 earthquake.

Figure 1 points out the main seismic sources of the broader Thessaloniki area, as provided by the Greek Database of Seismogenic Sources (GreDaSS: http://gredass.unife.it/; Caputo et al., 2012), a repository of geological, tectonic and active fault data for the Greek territory, together with the epicentres of the historical events with moment magnitude $M_{\mathrm{W}}>6$ (events within the computational domain are selected). Data about the historical events are taken from Papazachos et al. (2000; 2010) and, specifically for the 1978 Volvi earthquake, from Roumelioti et al. (2007). The study area is characterised by an intense seismic activity with strong historical earthquakes, associated mainly to the Mygdonia Basin and the Anthemountas fault zone, with magnitude up to $\mathrm{M}_{\mathrm{w}}=6.8$. The boundary of the computational model, described in the following sections, is also indicated, as denoted by the superimposed blue box.

From a geological point of view, the Thessaloniki urban area is characterised by three main macro geological structures oriented in the NW-SE direction. Starting from the deepest one, these formations can be summarised as follows: (1) metamorphic substratum consisting of crystalline rocks (gneiss, epigneiss and green shists), which outcrops at the N-NE border of the city and reaches a depth larger than $500 \mathrm{~m}$ near the coastline in the W-WS direction; (2) sedimentary deposits, mainly of Neogene period, dominated by the red silty clay series, covering the bedrock basement beneath the city; (3) recent deposits consisting of clays, sands and pebbles of Holocene period. The definition of 3D thematic maps of these geologic formations together with their characterisation in terms of main geotechnical/geophysical properties have been addressed, first, by Anastasiadis et al. (2001) and, subsequently, by Apostolidis et al. (2004). In this work reference has been made to the 3D model produced by Apostolidis et al. (2004).

\section{The Numerical Simulation Method}

3D numerical simulations of seismic wave propagation have been performed using the Discontinuous Galerkin Spectral Elements Method (DGSEM) implemented in the open-source computer package called SPEED, SPectral Element in Elastodynamics with Discontinuous Galerkin (http://speed.mox.polimi.it/; Mazzieri et al., 2013). SPEED can handle the simulation of large-scale seismic wave propagation problems including the coupled effect of a seismic fault rupture, the propagation path through Earth's layers and localised geological irregularities, such as alluvial valleys. Based on a discontinuous version of the classical spectral element (SE) method, as explained in Antonietti et al. (2012), SPEED is naturally oriented to solve multi-scale numerical problems, allowing one to use non-conforming meshes ( $h$-adaptivity) and different polynomial approximation degrees ( $N$-adaptivity) in the numerical model. The code has been optimised to run on multi-core computers and large clusters (e.g., Fermi BlueGene/Q at CINECA), taking advantage of the hybrid MPI-OpenMP parallel programming. The present version of SPEED includes the following features: i) different seismic excitation modes, including kinematic finite-fault seismic ruptures models; ii) both linear and non-linear visco-elastic soil materials; iii) different attenuation models with frequency proportional quality factor (Stupazzini et al., 2009) or frequency constant quality factor (Mozco et al., 2014); (iv) paraxial absorbing boundary conditions (Stacey, 1988); (v) time integration by either the second order accurate explicit leap-frog scheme or the fourth order accurate explicit Runge-Kutta scheme. Note that the current version SPEED cannot account for coupled fluidsoil seismic wave propagation analyses. 


\section{Computational Model for the Thessaloniki Urban Area}

Based on the available data regarding both the characterisation of the seismic sources and geological, geotechnical and geophysical aspects, a large-scale 3D spectral element model (see Figure 2) has been constructed, including the following features, as key ingredients:

- ground topography as retrieved from 90 m SRTM DEM (http://srtm.csi.cgiar.org/);

- four seismogenic fault sources posing a hazard to the city of Thessaloniki, specifically, Gerakarou-GRIS101 (i.e., the fault responsible of the 1978 Volvi earthquake), LangadhasGRIS102, Angelochori-GRIS251, and Souroti-GRIS252 (the latter two being part of the Anthemountas fault zone);

- horizontally layered crustal model for deep rock materials (from Ameri et al., 2008);

- 3D subsoil model of the Thessaloniki urban area, based on the detailed microzonation geotechnical studies (Anastasiadis et al., 2001) combined with extensive geophysical analyses (Apostolidis et al., 2004). Further details about the 3D subsoil model are given below.

As depicted in Figure 2, the mesh extends over a volume of about $82 \mathrm{~km} \mathrm{x} 64 \mathrm{~km} \mathrm{x} 31 \mathrm{~km}$ and is discretised using an unstructured hexahedral conforming mesh with characteristic element size ranging from a minimum of about $\sim 150 \mathrm{~m}$ at the surface to $\sim 1500 \mathrm{~m}$ at the bottom of the model. The model consists of 753'211 spectral elements, resulting in approximately 60 million of total degrees of freedom, with a third order polynomial approximation degree. Considering a rule of thumb of four grid points per minimum wavelength for non-dispersive wave propagation in heterogeneous media by the SE approach (Faccioli et al., 1997), this model can propagate frequencies up to about $2 \mathrm{~Hz}$. Provided that the mesh honours the geometry of different faults, as highlighted in Figure 2, this model can be used for generating ground motion scenarios in the city of Thessaloniki, resulting from fault ruptures involving either a portion or the entire length of any of these seismogenic sources.

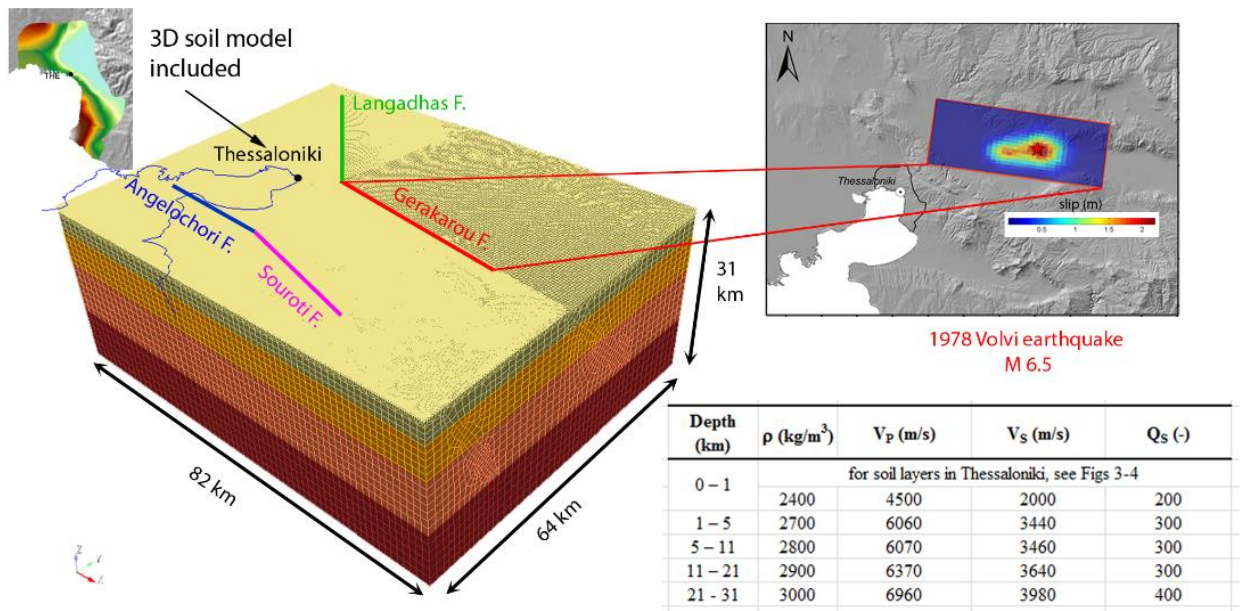

Figure 2 - 3D spectral element mesh for the broader Thessaloniki area. The crustal model, the faults included in the model and the slip distribution for the 1978 Volvi earthquake are also shown.

Regarding the 3D basin model, the following assumptions were made: (i) the 3D geometry of the geologic bedrock basement, as published in Apostolidis et al. (2004), was implemented in the numerical model (see Figure 3, left panel); (ii) two generic soil profiles with linear visco-elastic behavior were defined for the alluvial deposits overlying the bedrock for two ground categories, i.e. Eurocode $8(\mathrm{EC} 8)$ soil B $\left(\mathrm{V}_{\mathrm{S} 30}=360-800 \mathrm{~m} / \mathrm{s}\right)$ and $\mathrm{C}\left(\mathrm{V}_{\mathrm{S} 30}=180-360 \mathrm{~m} / \mathrm{s}\right)$, following the soil classification mapped in Figure 3 (right panel, from Pitilakis et al., 2015). 
- The soil profiles in terms of $\mathrm{S}$ - and $\mathrm{P}$ - wave velocity $\left(\mathrm{V}_{\mathrm{S}}\right.$ and $\mathrm{V}_{\mathrm{P}}$, respectively), soil density $(\rho)$ and quality factor $\left(Q_{S}\right)$, are given in Figure 4. The functional form for the $V_{S}$ gradient, $\mathrm{V}_{\mathrm{S}}(\mathrm{z})=\mathrm{V}_{\mathrm{S}, \mathrm{I}}+\left(\mathrm{V}_{\mathrm{S}, \mathrm{m}}-\mathrm{V}_{\mathrm{S}, 1}\right) \cdot(\mathrm{z} / \mathrm{h})^{0.70}$, with $\mathrm{V}_{\mathrm{S}, \mathrm{l}}=300 \mathrm{~m} / \mathrm{s}$ and $\mathrm{V}_{\mathrm{S}, \mathrm{m}}=2000 \mathrm{~m} / \mathrm{s}$ being the lower and upper $\mathrm{V}_{\mathrm{S}}$ at ground surface and top of geologic bedrock, respectively, and $\mathrm{h}=1000 \mathrm{~m}$, was defined according to the recent findings achieved in the framework of NERA project, based on empirical data from SHARE-AUTH database (Pitilakis et al., 2014). Note that a minimum shear wave velocity of $300 \mathrm{~m} / \mathrm{s}$ was assumed due to computational reasons, even though it overestimates the actual values especially along the shoreline. A frequency proportional quality factor is assumed using a reference frequency of $0.67 \mathrm{~Hz}$.

- Note that, although well constrained data were available only for the Thessaloniki urban area, it was necessary to extend arbitrarily the basin model to the west/south-west (Axios basin and Thermaikos gulf) and to the south-southeast (Anthemountas basin). To this end, the shape of the bedrock-alluvial interface along the NW-SE edge of the model by Apostolidis et al. (2004) was replicated along these directions to follow roughly the general geomorphologic features of the area. Several preliminary simulations tests were performed to check the impact of this extrapolation procedure, pointing out that results are affected only to a minor extent.
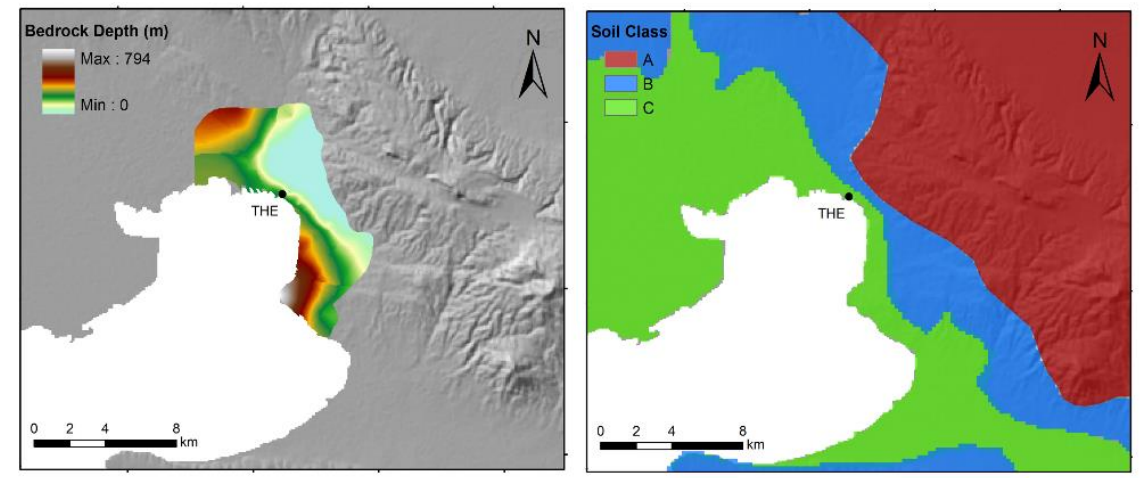

Figure 3 - Left: 3D map showing the depth of geologic bedrock (after Apostolidis et al., 2004) within the city of Thessaloniki; Right: EC8 soil classification (based on Pitilakis et al., 2015).
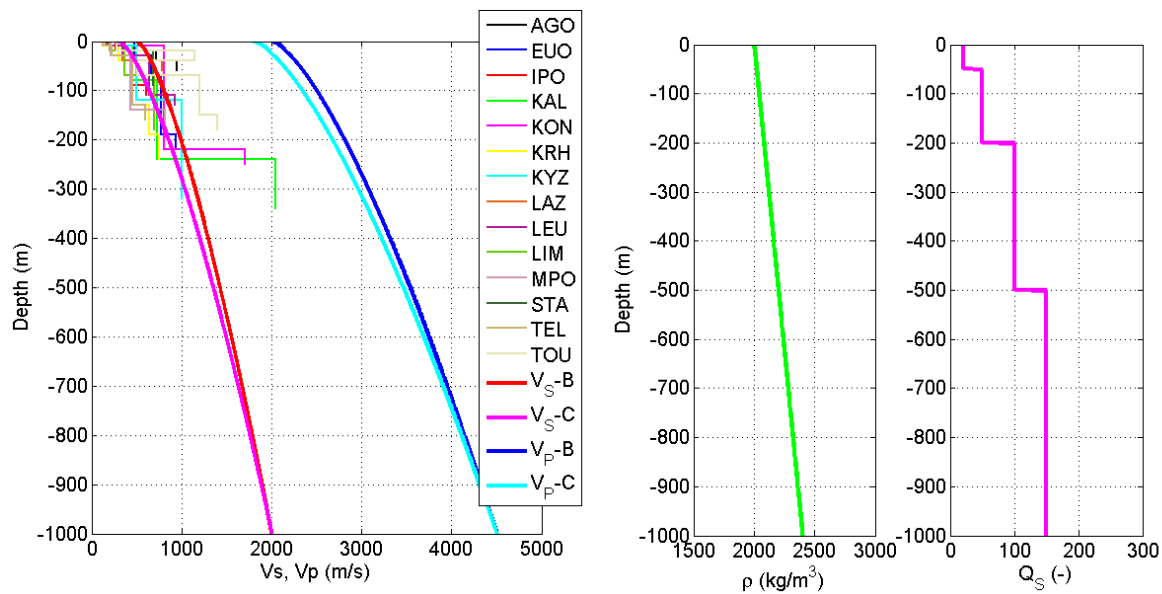

Figure 4-Calibration of average soil profiles in terms of $V_{s}, V_{P}, \rho$ and $Q_{s}$ (at a reference frequency $f_{0}=0.67 \mathrm{~Hz}$ ) for the $3 \mathrm{D}$ model, based on the available $1 \mathrm{D}$ data. 


\section{Numerical Simulation of the 20 June 1978 Volvi Earthquake}

As a case study, the $\mathrm{M}_{\mathrm{W}} 6.5$ June 201978 Volvi earthquake was simulated by SPEED. Even though there was only one strong motion station in operation during the earthquake and the quality of the available recordings is rather low, it is interesting to analyse the main features of the predicted ground motion during this major event.

To simulate the Volvi earthquake, in addition to the features illustrated in the previous section, a kinematic source model along the Gerakarou fault was considered. Reference was made to the recent work by Roumelioti et al. (2007), who investigated the rupture process of the 1978 earthquake from the analysis of teleseismic waveforms, recorded in the distance range $21^{\circ}$ to $37^{\circ}$, combined with near-fault levelling data. The main kinematic source parameters are listed in Table 1 while the slip distribution is shown in Figure 2. Based on the results of preliminary comparisons between synthetics and observations using the Hisada code (Hisada and Bielak, 2003), the following modifications were made with respect to the model published by Roumelioti et al. (2007): (i) the top depth of rupture as assumed at $1 \mathrm{~km}$ to avoid super-shear effects $\left(\mathrm{V}_{\mathrm{S}}\right.$ in the top layer is, in fact, $2 \mathrm{~km} / \mathrm{s}$ ); (ii) for the slip distribution, we used a $k^{2}$ slip model (Herrero and Bernard, 1994), with location and size of the main slip asperities resembling the ones in the original model.

It was, in fact, found that the application of the original finite-fault solution, characterised by a significant slip asperity at ground surface (as inferred from levelling data), in conjunction with the assumed crustal model, may induce unrealistic ground motion amplitudes towards the city of Thessaloniki owing to excessive amplification effects at the resonance frequency of the first layer of the crustal model, i.e. at $0.5 \mathrm{~Hz}$, where the source radiates much energy. To clarify these effects, Figure 4 shows the results (velocity histories and corresponding Fourier Amplitude Spectra, FAS) at the accelerometric station THE-City Hotel (see location in Figure 3) for the kinematic slip model by Roumelioti et al. (2007) under two hypotheses regarding the crustal model, i.e., with or without the top layer of $2000 \mathrm{~m} / \mathrm{s}$. It is apparent that the case with the top layer produces excessive energy in the frequency range between $0.5-1 \mathrm{~Hz}$, especially on the EW and UP component.
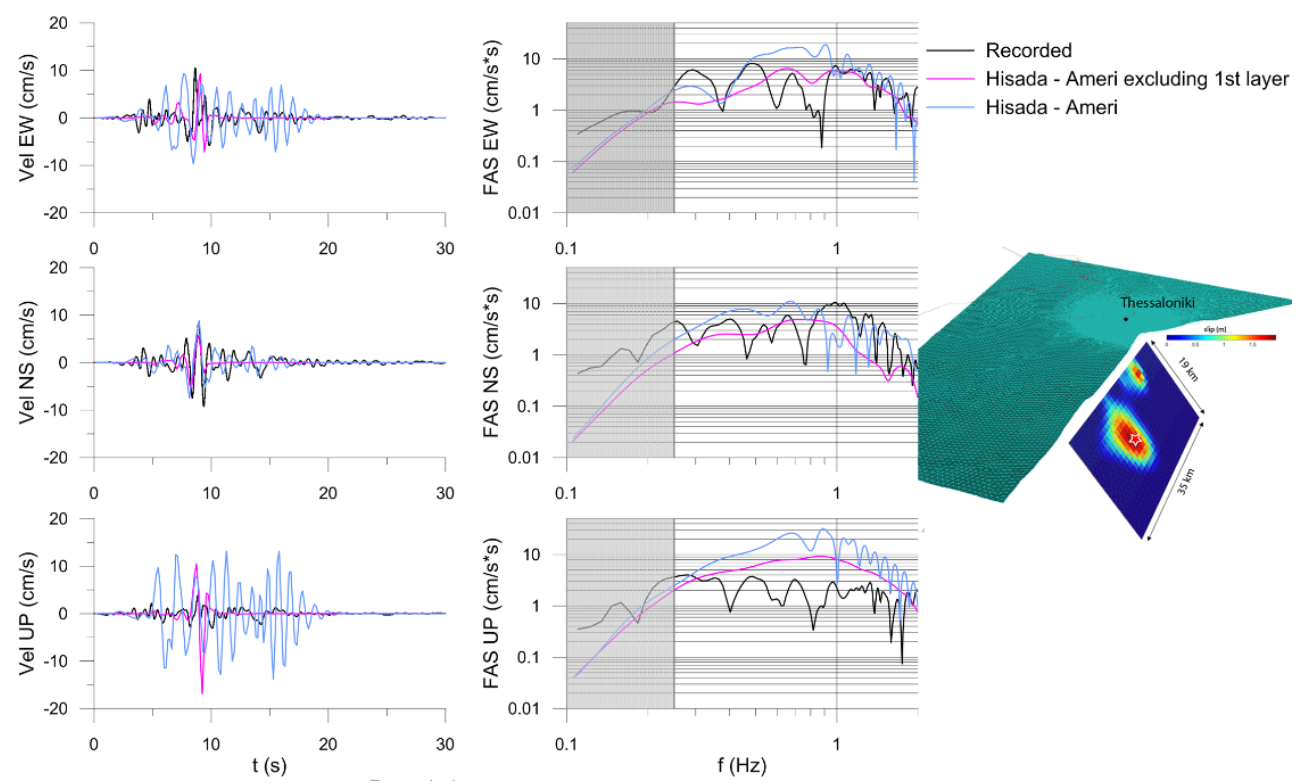

Figure 5 - Effect of the crustal model and kinematic slip distribution. Results refer to the THE-City Hotel station (see location in Figure 3) in the range 0.25-2 Hz.

Figure 5 shows the comparison between synthetics and ground motion observations at the accelerometric station THE-City Hotel in terms of velocity waveforms and FAS. Recorded motions 
were downloaded from ITSAK database (http://www.itsak.gr/). Both simulated and recorded data are band-pass filtered between 0.25 and $2 \mathrm{~Hz}$, the former being the minimum usable frequency of the analog record and the latter being the frequency limit of the numerical simulation. A satisfactory agreement is found especially for the horizontal components, especially the NS one, while vertical component tend be overestimated, due to the assumptions regarding the assumed focal mechanism.

Table 1 - Summary of main source parameters for the 1978 Volvi earthquake.

\begin{tabular}{|c|c|c|c|c|c|c|}
\hline $\begin{array}{c}\text { Hypocentre } \\
\left({ }^{\circ} \mathbf{N},{ }^{\circ} \mathrm{E}\right)\end{array}$ & $\begin{array}{c}\text { Depth } \\
(\mathbf{k m})\end{array}$ & $\begin{array}{c}\mathbf{L} \mathbf{x} \text { W } \\
\left(\mathrm{km}^{2}\right)\end{array}$ & $\begin{array}{c}\mathbf{Z}_{\text {top }} \\
(\mathbf{k m})\end{array}$ & $\begin{array}{c}\text { Strike/Dip/Rake } \\
\left({ }^{\circ}\right)\end{array}$ & $\begin{array}{c}\text { Rup. } \\
\text { Vel. } \\
(\mathbf{k m} / \mathbf{s})\end{array}$ & $\begin{array}{c}\text { Rise } \\
\text { Time } \\
(\mathbf{s})\end{array}$ \\
\hline$(40.705,23.266)$ & 7.5 & $35 \times 19$ & 1 & $278 / 46 /-70$ & 2.6 & 0.6 \\
\hline
\end{tabular}
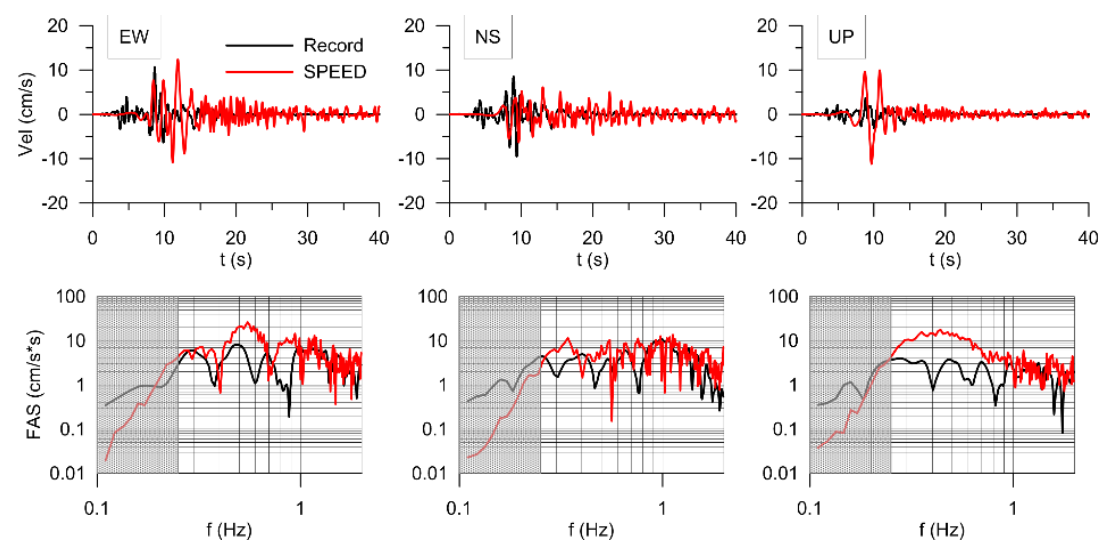

Figure 6 - Comparison between synthetics and recordings at the THE-City Hotel station: three component velocity time histories (top) and FAS (bottom) in the range $0.25-2 \mathrm{~Hz}$.

Finally, as a further check on the results of the numerical simulations on a broad scale, Figure 5 illustrates the comparison with the GMPE by Skarlatoudis et al. (2003, 2007), SK07, developed specifically for shallow earthquakes in the broader Aegean area, in terms of geometric mean of PGV, considering a set of uniformly spaced sites on rock (left) and basin (right) conditions. A satisfactory comparison is found especially for rock and stiff soil sites, while at soft basin sites (EC8 class C) larger differences are found probably due to the inability of the empirical models to account for the specificity of local site conditions.

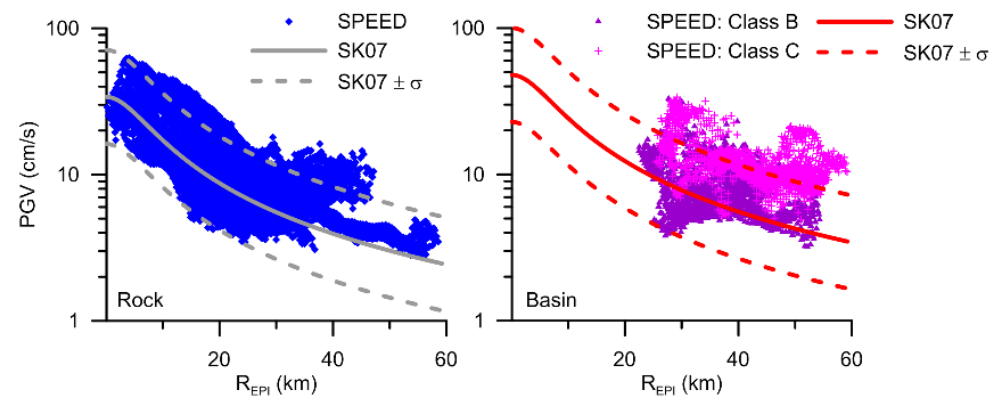

Figure 7 - Comparison between simulated results and the GMPE of Skarlatoudis et al. (2003, 2007), SK07, for both rock (left) and basin (right) sites. 


\section{Ground Shaking Maps}

Interesting outputs of 3D numerical simulations are the ground shaking maps at a broad scale in terms of different ground motion intensity measures, such as Peak Ground Velocity (PGV), Peak Ground Displacement (PGD) or response spectral acceleration (SA). In Figure 6 the spatial distribution of PGV (filtered in the range $0.05-2 \mathrm{~Hz}$ ) is shown for the three components of ground motion: normal to the fault strike (Fault Normal, FN), parallel to the fault strike (Fault Parallel, FP) and vertical (UP). For comparison purposes, the same colour scale has been adopted for the three maps. It is found that maximum PGV values of about $1.15 \mathrm{~m} / \mathrm{s}$ are found on the hangingwall of the fault on the FN component, while the FP ground motions tend to be significant lower in the near field. However, at larger distances, differences between the FN and FP tends to decrease significantly. Vertical motion can be larger than the horizontal FP motion in the near-source region, in agreement with the evidence of larger vertical to horizontal ratios in the proximity of the source (see e.g. Ambraseys and Douglas, 2003). From both maps it is found that maximum ground motion amplitudes are found in the region, south-east of the epicentre owing to focal mechanism effects. At larger distances, amplification of ground motion due to the presence of the soft sedimentary deposits is also apparent.

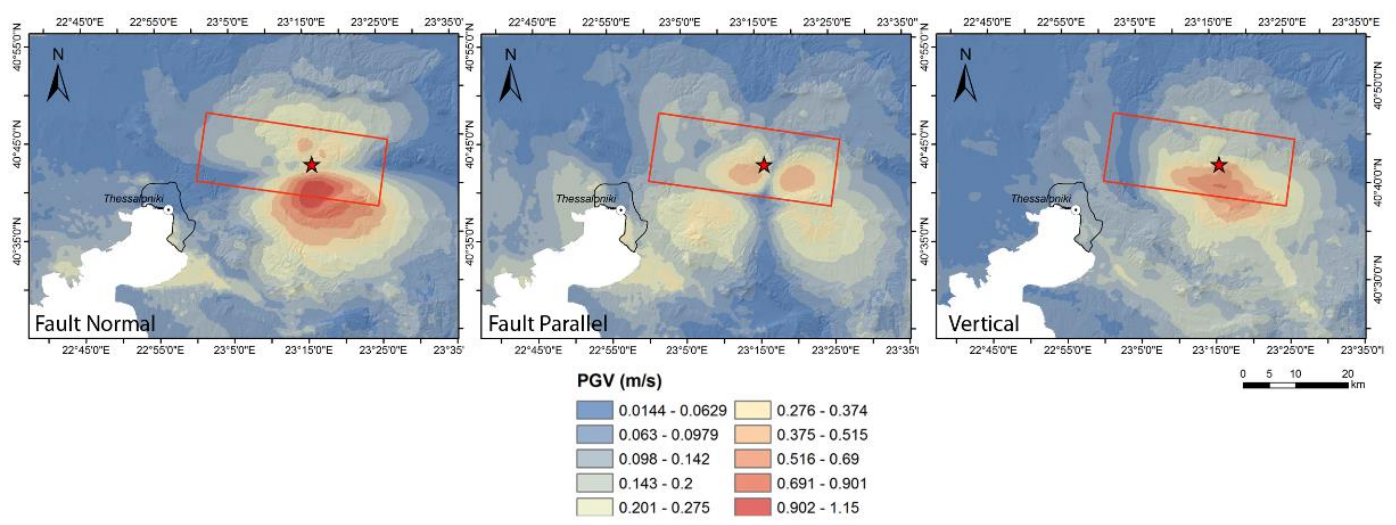

Figure 8 - Map of Peak Ground Velocity (PGV) on the Fault Normal (FN, left), Fault Parallel (FP, centre) and vertical (UP, right) component.

\section{Conclusions}

In this paper 3D numerical modelling of earthquake ground motion in the Thessaloniki urban area has been addressed with emphasis on the simulation of the destructive $M_{W} 6.520$ June 1978 earthquake, who affected seriously the city. The model covers a wide area of size $82 \mathrm{~km} \times 64 \mathrm{~km}$ and includes the 3D subsoil structure of the urban area, as retrieved from the available geotechnical and geophysical studies, as well as the fault sources posing a serious threat to the city of Thessaloniki.

The first efforts to study 3D seismic wave propagation effects within the Thessaloniki urban area at a wide scale were made by Skarlatoudis et al. (2010, 2011, 2012), who adopted a finite-difference numerical approach. Compared to these numerical studies, in our modelling extended finite-fault rupture models have been addressed rather than point-source representations. However, a more simplified description of the subsoil structure has been adopted herein owing to computational reasons.

The available strong motion data, i.e., only one rather poor record at the basement of a high rise building, are not sufficient to carry out a comprehensive validation study. The comparison between recordings and synthetics at this strong motion station points out some discrepancies especially in the EW and UP components, probably due to the assumptions regarding the kinematic source model (focal mechanism and slip distribution). However, in this study, emphasis is given to the complex modeling of 3D seismic wave propagation, including a variety of factors, from the extended fault rupture to local site effects in Thessaloniki, to prove that this kind of analysis is now feasible and 
can reproduce in a satisfactory way the general features of spatial variability of ground motion at broad scale. Comparison with GMPEs is addressed and ground shaking maps in terms of PGV are provided to shed light on the most significant wave propagation effects (near-fault, focal mechanism and site effects). The model presented in this study may be used for generating various ground shaking scenarios from future earthquakes originating from the Gerakarou, Langadhas or Anthemountas seismogenic sources of potential major impact on the city of Thessaloniki.

\section{Acknowledgments}

This study has been carried out in the framework of the STREST Project "Harmonised approach to stress tests for critical infrastructures against natural hazards", EU FP7/2007-2013, grant agreement no. 603389. The contributions of different researchers of the Aristotle University of Thessaloniki, namely Dr. Zafeiria Roumelioti, Dr. Maria Manakou, Dr. Sotiris Argyroudis, Dr. Evi Riga and Prof. Dimitrios Raptakis, are greatly acknowledged. The remarks of two anonymous reviewers helped improve the quality of the paper. Finally, the authors are indebted to the staff of the AUTH Scientific Computing Center (SCC), in particular to Alexandra Charalampidou and Paschalis Korosoglou, for allowing the extensive use of the AUTH cluster and for providing technical support.

\section{References}

Ambraseys, N. and Douglas, J., 2003. Near-field horizontal and vertical earthquake ground motions, Soil Dyn. Earthq. Eng., 23, 1-18.

Ameri, G., Pacor, F., Cultrera, G. and Franceschina, G., 2008 Deterministic ground-motion scenarios for engineering applications: the case of Thessaloniki, Greece, Bull. Seism. Soc. Am., 98(3), 1289-1303.

Anastasiadis, A., Raptakis, D. and Pitilakis, K., 2001. Thessaloniki's detailed microzoning: subsurface structure as basis for site response analysis, Pure appl. Geophys., 158, 2597-2633.

Antonietti, P.F., Mazzieri, I., Quarteroni, A. and Rapetti, F., 2012. Non-conforming high order approximations of the elastodynamics equation, Comp. Meth. Appl. Mech. Eng., 209-212, 212-238.

Apostolidis, P., Raptakis, D., Roumelioti, Z. and Pitilakis, K., 2004. Determination of S-wave velocity structure using microtremors and SPAC method applied in Thessaloniki (Greece), Soil Dyn. Earthq. Eng., 24, 49-67.

Caputo, R., Chatzipetros, A., Pavlides, S. and Sboras, S., 2012. The Greek Database of Seismogenic Sources (GreDaSS): state-of-the-art for norther Greece, Annals Geophys., 55(5), 859-894.

Faccioli, E., Maggio, F., Paolucci, R. and Quarteroni, A., 1997. 2D and 3D elastic wave propagation by a pseudo-spectral domain decomposition method, J. Seismol., 1(3), 237-251.

Herrero, A. and Bernard, P., 1994. A kinematic self-similar rupture process for earthquakes, Bull. Seism. Soc. Am., 84(4), 1216-1228.

Hisada, Y. and Bielak, J., 2003. A theoretical method for computing near-fault ground motions in layered half-spaces considering static offset due to surface faulting, with a physical interpretation of fling step and rupture directivity, Bull. Seism. Soc. Am., 93(3), 1154-1168.

Lachet, C., Hatzfeld, D., Bard, P.-Y., Theodulidis, N., Papaioannou, Ch. and Savvaidis, A., 1996. Site effects and microzonation in the city of Thessaloniki (Greece) comparison of different approaches, Bull. Seism. Soc. Am., 86, 1692-1703.

Mazzieri, I., Stupazzini, M., Guidotti, R. and Smerzini, C., 2013. SPEED: Spectral elements in elastodynamics with Discontinuous Galerkin: a non-conforming approach for 3D multi-scale problems, Int. J. Numer. Meth. Eng., 95(12), 991-1010.

Mozco, P., Kristek, J. and Galis, M., 2014. The Finite-Difference modelling of earthquake motions: waves and ruptures, Cambridge University Press.

Papazachos, B.C., Comninakis, P.E., Karakaisis, G.F., Karakostas, B.G., Papaioannou, C., Papazachos, C.B. and Scordilis, E.M., 2000. A catalogue of earthquakes in Greece and surrounding area for the period 550BC-1999, Publ. Geophys. Laboratory, University of Thessaloniki, 1, 333 pp. 
Papazachos, B.C., Comninakis, P.E., Scordilis, E.M., Karakaisis, G.F. and Papazachos, C.B., 2010. A catalogue of earthquakes in the Mediterranean and surrounding area for the period 1901 2010, Publ. Geophys. Laboratory, University of Thessaloniki.

Paradisopoulou. P.M., Karakostas, V.G., Papadimitriou, E.E., Tranos, M.D., Papazachos, C.B. and Karakaisis, G.F., 2006. Microearthquake study of the broader Thessaloniki area (Northern Greece), Annals Geophys., 49(4/5), 1081-1093.

Pitilakis, K., Riga, E., Makra, K., Gelagoti, F., Ktenidou, O-J., Anastasiadis, A., Pitilakis, D. and Izquierdo Flores, C.A., 2014. Deliverable D11.5 Code cross-check, computed models and list of available results - AUTH contribution, Network of European Research Infrastructures for Earthquake Risk Assessment and Mitigation (NERA), Seventh Framework Programme, EC project number: 262330.

Pitilakis, K., Riga, E. and Anastasiadis, A., 2015. New design spectra in Eurocode 8 and preliminary application to the seismic risk of Thessaloniki, Greece. In: Ansal, A. and Sakr, M., eds., Perspectives on Earthquake Geotechnical Engineering, Series: Geotechnical, Geological and Earthquake Engineering, 37, Springer Netherlands, 45-91.

Raptakis, D., Makra, K., Anastasiadis, A. and Pitilakis, K., 2004a. Complex site effects in Thessaloniki (Greece). Part I. Soil structure and comparison of observations with 1D analysis, Bull. Earth. Eng., 2, 271-300.

Raptakis, D., Makra, K., Anastasiadis, A. and Pitilakis, K., 2004b. Complex site effects in Thessaloniki (Greece). Part II. 2D SH modeling and engineering insights, Bull. Earth. Eng., 2, 301-327.

Roumelioti, Z., Theodulidis, N. and Kiratzi, A., 2007. The 20 June 1978 Thessaloniki (Northern Greece) earthquake revisited: slip distribution and forward modelling of geodetic and seismological observations, $4^{\text {th }}$ International Conference on Earthquake Geotechnical Engineering, June 25-28, Paper no. 1594.

Skarlatoudis, A.A., Papazachos, C.B., Margaris, B.N., Theodulidis, N., Papaioannou, C., Kalogeras, I., Scordilis, E.M. and Karakostas, V., 2003. Empirical peak ground-motion predictive relations for shallow earthquake in Greece, Bull. Seism. Soc. Am., 93(6), 2591-2603.

Skarlatoudis, A.A., Papazachos, C.B., Margaris, B.N., Theodulidis, N., Papaioannou, C., Kalogeras, I., Scordilis, E.M. and Karakostas, V., 2007. Erratum of "Empirical peak ground-motion predictive relations for shallow earthquake in Greece, Bull. Seism. Soc. Am., 93(6), 2591-2603.

Skarlatoudis, A.A., Papazachos, C.B., Theodoulidis, N., Kristek, J. and Moczo, P., 2010. Local siteeffects for the city of Thessaloniki (N. Greece) using a 3-D finite-difference method: a case of complex dependence on source and model parameters, Geophy. J. Int., 182, 279-298, doi: 10.1111/j.1365-246X.2010.04606.x.

Skarlatoudis, A.A., Papazachos, C.B. and Theodoulidis, N., 2011. Spatial distribution of site effects and wave propagation properties in Thessaloniki (N. Greece) using a 3-D finite difference method, Geophy. J. Int., 185, 485-513, doi: 10.1111/j.1365-246X.2011.04954.x.

Skarlatoudis, A.A., Papazachos, C.B. and Theodoulidis, N., 2012. Site-Response Study of Thessaloniki (Northern Greece) for the 4 July 1978 M 5.1 Aftershock of the June 1978 M 6.5 Sequence Using a 3D Finite-Difference Approach, Bull. Seism. Soc. Am., 102(2), 722-737.

Stacey, R., 1988. Improved transparent boundary formulations for the elastic-wave equation, Bull. Seism. Soc. Am., 78(6), 2089-2097.

Stupazzini, M., Paolucci, R. and Igel, H., 2009. Near-fault earthquake ground-motion simulation in Grenoble Valley by high-performance spectral element code, Bull. Seism. Soc. Am., 99(1), 286-301.

Tranos, M.D., Papadimitriou, E.E. and Kilias, A.A., 2003. Thessaloniki-Gerakarou fault zone (TGFZ): the western extension of the 1978 Thessaloniki earthquake fault (Northern Greece) and seismic hazard assessment, J. Struct. Geol., 25, 109-2123.

Triantafyllidis, P., Suhadolc, P., Hatzidimitriou, P.M., Anastasiadis, A. and Theodulidis, N., 2004a. Part I. Theoretical site response estimation for microzoning purposes, Pure appl. Geophys., $161,1185-1203$.

Triantafyllidis, P., Hatzidimitriou, P.M, Suhadolc, P., Theodulidis, N. and Anastasiadis, A., 2004b. Part II. Comparison of theoretical and experimental estimations of site effects, Pure appl. Geophys., 161, 1205-1219. 


\title{
SEISMIC HAZARD ASSESSMENT IN THE NORTH AEGEAN TROUGH BASED ON A NEW SEISMOGENIC ZONATION
}

\author{
Stylianou E. ${ }^{1}$, Maravas G. ${ }^{1}$, Kouskouna V. ${ }^{1}$ and Papoulia J. \\ ${ }^{I}$ National \& Kapodistrian University of Athens, Department of Geology, Athens, Greece, \\ kouskouna@geol.uoa.gr \\ ${ }^{2}$ Hellenic Centre for Marine Research, Institute of Oceanography, Anavissos, Greece, \\ jpapoulia@gmail.com
}

\begin{abstract}
The quantification of uncertainties and choise of the seismogenic zonation are crucial points in the probabilistic assessment of seismic hazard. This study followed the structure of a "logic tree" of 16 branches, in order to quantify uncertainties. It consists of two seismogenic zonations - one specifically developed for the North Aegean Trough based on recent swath mapping, geophysical and seismotectonic data, and the regional zonation used in the seismic hazard map of Greece. Two different approaches for the seismicity model definition and four attenuation relationships valid for Greece were used. The assessment of seismic hazard was obtained using the CRISIS software. All seismic hazard maps refer to the horizontal peak ground acceleration (PGA) with 475 years return period. Using the new developed zonation, maximum PGA values of 300 Gal are associated with the North Sporades area and the deepest part of the North Sporades basin. Results obtained by the regional seismogenic zonation of Greece shift maximum PGA values northeast of Athos peninsula. We conclude that the new zonation produces results that better address the seismotectonic regime of the North Aegean area. Keywords: logic tree, CRISIS software, Greece.
\end{abstract}

\section{Пврі́ $\eta \psi \eta$}

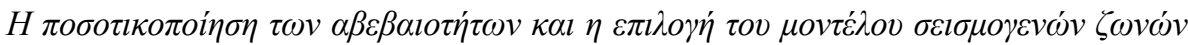

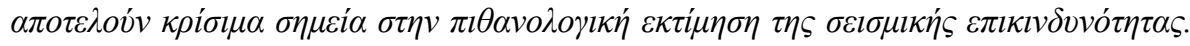

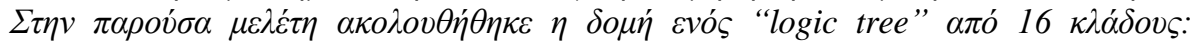

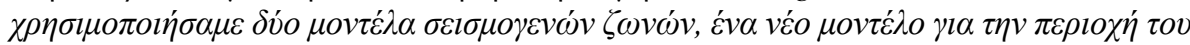

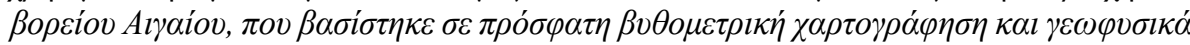

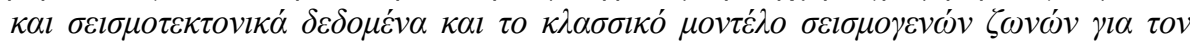

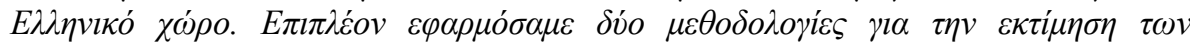

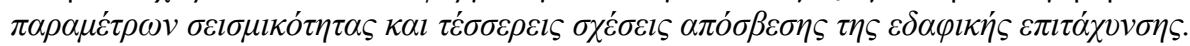

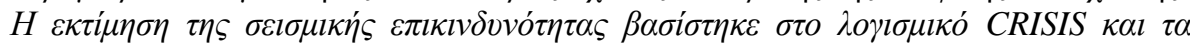

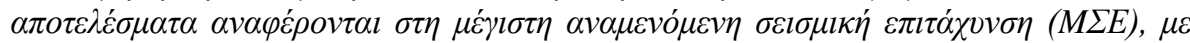

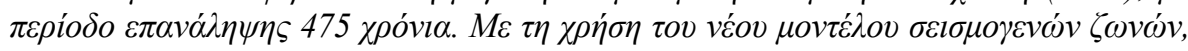

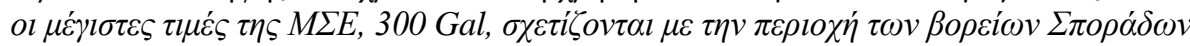

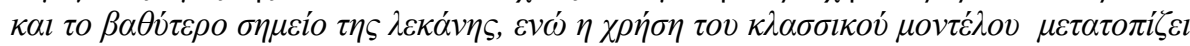

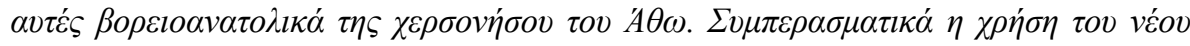

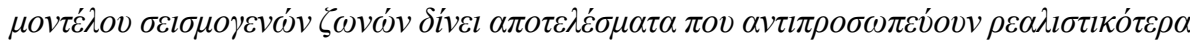

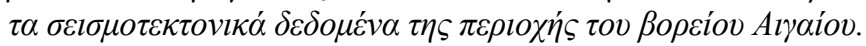

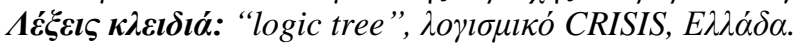




\section{Introduction}

The most prominent tectonic feature of the North Aegean Sea is the North Aegean Trough (NAT), consisting of a series of deep fault-bounded seismically active basins, like those of Saros and north Sporades (e.g. Le Pichon et al., 1984; Papanikolaou et al., 2006; Pavlides et al., 2008) (see fig. 1). The prevailing tectonic regime is extensional associated with dextral strike-slip transtension (e.g. Lyberis, 1984; Ginzburg et al., 1986; Papazachos and Papazachou, 2003). Right-lateral strike-slip faults within the Trough and the surrounding region accommodate the westward motion of the North Anatolia Fault (NAF) and the south-westward motion of the Aegean microplate relative to Eurasia. This is also clearly mapped by GPS observations (Kahle et al., 1998).

The westward extension and termination of the NAF in the Aegean domain is a matter of dispute and has been discussed by many authors. McKenzie (1972) and LePichon et al. (1984) suggested an extension of NAF with two major extensional rifts, this of Sperchios basin and even more so the Corinth basin rift. Makris (1977, 1985), based on gravity observations and seismic reflection and refraction profiles, proposed that the shear of the NAF is dissipated into a number of major dislocations and tensional and sheared features across the north Aegean Sea and the Hellenides (see also Makris and Stobbe, 1984; Ginzburg et al., 1986).

Brooks and Ferentinos (1980), based on single channel reflection seismic mapping, showed that faulting in the basins has caused significant post orogenic gravitational slumping, and deformed the sea bottom topography. Ginzburg et al. (op cited) accomplished a detailed multichannel seismic reflection and refraction study and showed that the crust in the NAT is continental, $28 \mathrm{~km}$ thick (Moho depth), overlain by sediments of 5 to $5.5 \mathrm{~km}$ thickness. They proposed that the origin of the present-day NAT is the result of a Miocene extension and down warping of the crust accompanied by sedimentation of Neogene and younger sediments. Also Makris et al. (2001), from refraction seismic data, and Makris et al. (2013), from 3D density modelling constrained by gravity and seismic information, showed that crustal thickness in the NAT is $26-28 \mathrm{~km}$, and average thickness of sediments about 5 - $6 \mathrm{~km}$, having maximum values in the north Sporades and Saros basins (see also Lalechos and Savoyat, 1979). These basins, as mentioned above, are developing by transtension in a continental domain.

The northern Aegean Sea is the host of many moderate-to-large earthquakes. Several of these are located along the NAT lineament, including the M 6.6 and 6.7 earthquakes of January 1982 and August 1983, the M 6.7 earthquake of March 1975 (Papazachos and Papazachou, 2003), and the Mw 6.3 of the eastern segment of NAT (Sboras et al., 2015). The largest earthquake was the Mw 6.9 event in 2014 in in the Saros basin (Saltogianni et al., 2015). The broader NAT region is one of the most seismically active areas in the Aegean domain. It is therefore of primary importance for the safety of a fairly densely populated area to have a reliable seismic hazard model. In this paper we present a seismic hazard assessment based on the most advanced state of the art techniques and the latest geophysical and geological information.

\section{The earthquake catalogue}

The earthquake catalogue used in the present study was derived from the homogenization of data from Papazachos et al. (2009), the Seismic Bulletins of Thessaloniki (http://geophysics.geo.auth.gr/ss/CATALOGS/seiscat.dat), the Seismic Bulletins of the National Observatory of Athens (http://gein.noa.gr/services/1950-00.txt), the catalogue of Papanastasiou et al. (2001), and the GCMT, Global Centroid Moment Tensor database of Harvard (http://www.globalcmt.org/CMTsearch.html). All double events were removed by using a FORTRAN code and the catalogues were unified (Scordilis, personal communication). Thus, 4,679 dependent events were eliminated from the original catalogue and the final data file used for estimating hazard includes 6,007 events with magnitude larger than 3.0 for the time period between 1900 and 2009 and between coordinates 21.00 - 26.50 E and 38.50 - 41.50 N. Individual magnitudes from the different catalogues were calibrated and a final magnitude was estimated, equivalent to the 
moment magnitude, Mw, for Greek earthquakes. A detailed description of the procedure followed for the homogenization and compilation of the new earthquake catalogue is given in Tsambas (2006) and Tsambas et al. (2016).

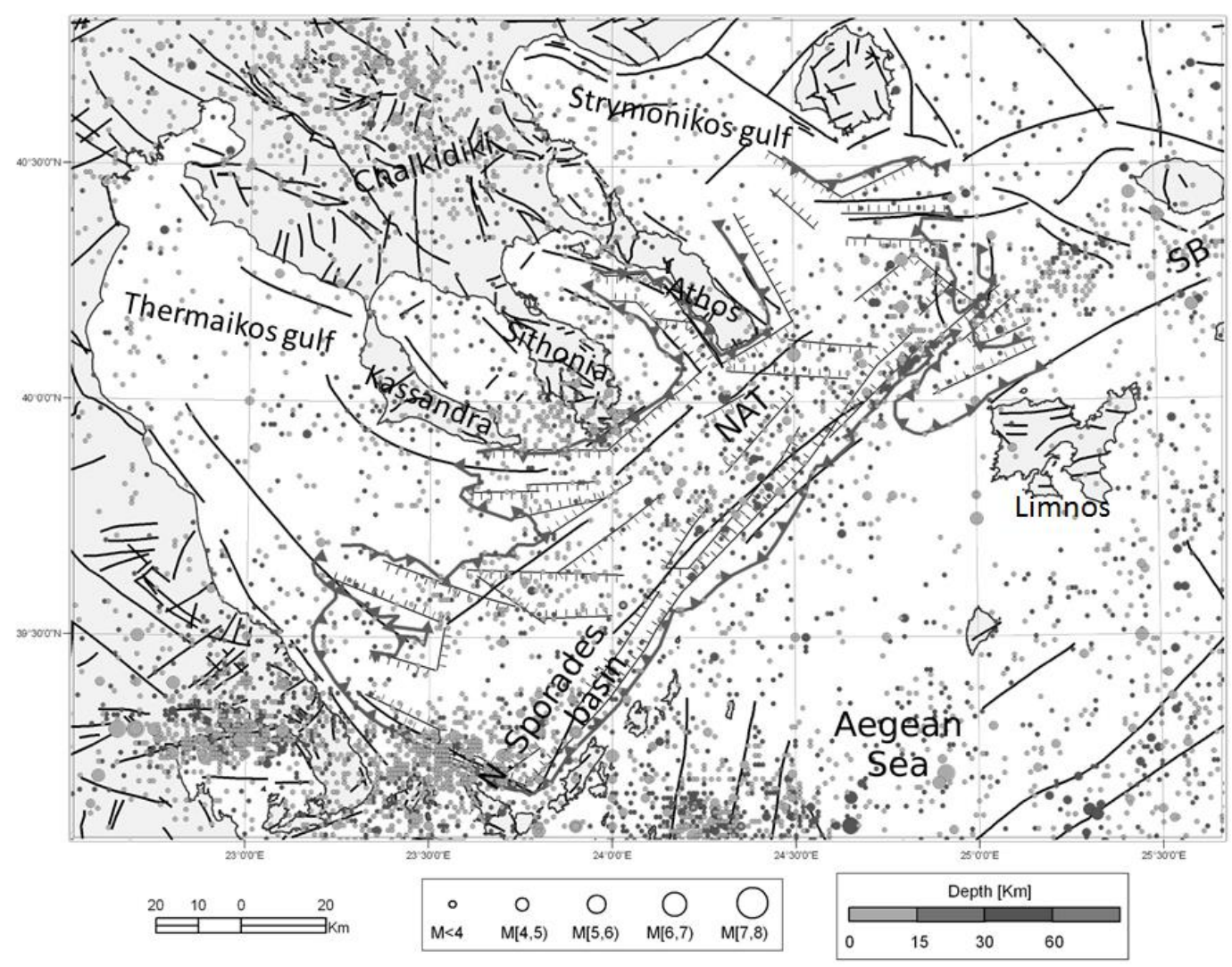

Figure 1 - Seismicity in the North Aegean Trough (NAT) and surrounding area. Faults adopted from IGME (1989), Papanikolaou et al. (2006) and Pavlides et al. (2008).

Earthquake data from Tsambas (2006) and Tsambas et al. (2016). NSB: North Sporades basin, SB: Saros basin.

\section{The new seismogenic zonation and seismicity parameters}

We designed a new seismogenic zonation (see fig. 2) considering the latest bathymetric and tectonic mapping based on swath bathymetry (Papanikolaou et al., 2006) of the North Aegean Trough, active faults mapping (Pavlides et al., 2008) and the seismotectonic data of IGME (1989). Distribution of earthquakes was obtained from the new homogenized catalogue. This new zonation provides the best fit between the tectonic regime and the seismicity. 


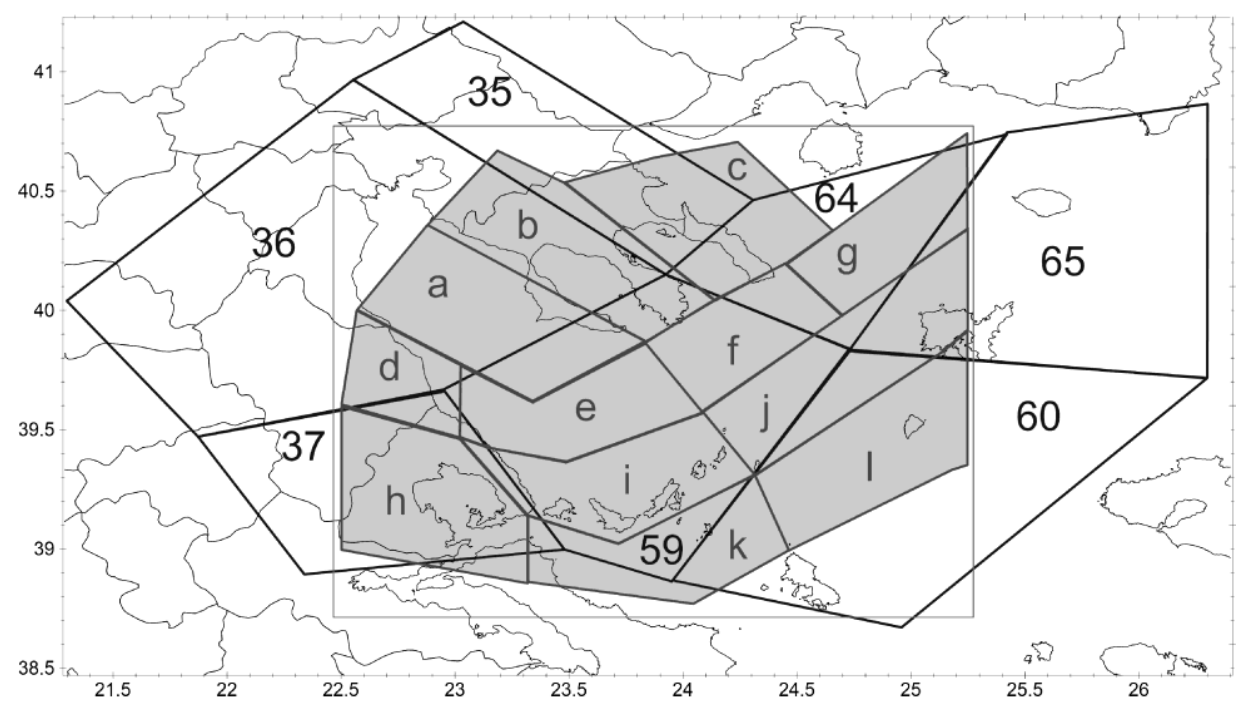

Figure 2 - The new proposed seismogenic zonation for the North Aegean Trough and surrounding region (shaded polygons) vs. the regional zonation of Papaioannou and Papazachos (2000) (white polygons). Frame indicates the area where hazard is estimated.

In order to estimate the influence of the seismogenic zonation on hazard estimates we also used the regional zonation published by Papaioannou and Papazachos (2000) and computed hazard maps using the same catalogue and attenuation relationships.

The seismicity parameters used as input for seismic hazard assessment by the CRISIS code (Ordaz et al., 2007) are summarized in Table 1 . The parameters a and b of earthquake recurrence have been computed for each SZ following two different approaches, the maximum likelihood (MLE) and the least squares method (LSQ).

The geological approach for the determination of MmaxGEO for a seismogenic zone is based on th e scaling law between surface rupture length $(S R L)$ and maximum magnitude as originally establis hed by Wells and Coppersmith (1994) for earthquakes in California. Pavlides and Caputo (2004) d eveloped a similar relation for the earthquakes of Greece that was adopted in the present study.

\section{The seismic hazard assessment of the North Aegean Trough}

The probabilistic seismic hazard assessment (PSHA) for the NAT broader area has been computed using the standard approach of Cornell (1968) and the CRISIS code of Ordaz et al. (op cited). A logic tree approach for PSHA (Kulkarni et al., 1984; Coppersmith and Youngs, 1986) was introduced for quantifying the uncertainties. Each node of the logic tree represents a specific constrain of the calculation by modifying the seismogenic source zonation, seismicity model, and the attenuation relationships, providing a series of alternative models (see fig. 3). Specifically, we considered two seismogenic zonations, the new designed zonation and the regional zonation (Papaioannou and Papazachos, op cited), and two methods for seismicity rates computation, the maximum likelihood and the least squares method. Finally, four attenuation relationships for horizontal peak ground acceleration (PGA) published for Greece by Margaris et al. (2002), Theodulidis and Papazachos (1994), Skarlatoudis et al. (2003), and Danciu and Tselentis (2007) were considered. Seismic hazard is presented in terms of maximum PGA with $10 \%$ probability of exceedance in 50 years (475 years return period). 
Table 1 - Seismicity parameters for the seismogenic zones in the North Aegean Trough and surrounding area. $N=$ number of earthquakes, $\mathbf{a}$ and $\mathrm{b}$ : parameters of the Gutenberg-Richter

law estimated by the maximum likelihood (MLE) and the least squares (LSQ) method. Mmaxobs= maximum observed magnitude, MmaxGEO= maximum geological magnitude, T.period $=$ period of observations.

\begin{tabular}{|c|c|c|c|c|c|c|c|c|}
\hline & N & $a$ (MLE) & $b$ (MLE) & a (LSQ) & b (LSQ) & Mmax obs & $M \max (\mathrm{GEO})$ & T. period \\
\hline \multicolumn{9}{|c|}{ Proposed Zonation } \\
\hline a & 107 & 4,68 & $-0,85$ & 5,22 & $-0,92$ & 6,4 & 6,8 & $1921-2009$ \\
\hline b & 146 & 5,83 & $-1,15$ & 5,25 & $\begin{array}{l}-1,01 \\
-1,0\end{array}$ & 6,5 & 6,9 & $1959-2009$ \\
\hline c & 176 & 4,99 & $-0,90$ & 5,20 & $\begin{array}{l}-0,98 \\
-0,9\end{array}$ & 7,0 & 7,2 & $1929-2009$ \\
\hline d & 16 & 2,33 & $-0,37$ & 2,24 & $-0,34$ & 6,4 & 6,6 & $1905-2009$ \\
\hline $\mathrm{e}$ & 130 & 5,11 & $-0,94$ & 4,89 & $-0,91$ & 6,1 & 7,1 & $1911-2009$ \\
\hline$f$ & 142 & 4,77 & $-0,82$ & 6,22 & $-1,08$ & 7,5 & 7,6 & $1905-2009$ \\
\hline g & 65 & 7,02 & $-1,26$ & 5,37 & $-0,94$ & 6,8 & 7,4 & $1947-2009$ \\
\hline h & 203 & 4,70 & $-0,77$ & 5,14 & $-0,93$ & 6,8 & 7,2 & $1909-2009$ \\
\hline $\mathrm{i}$ & 186 & 4,25 & $-0,63$ & 6,32 & $-1,02$ & 6,1 & 7,4 & 1903-2009 \\
\hline $\mathbf{j}$ & 104 & 4,56 & $-0,78$ & 5,20 & $-0,91$ & 7,0 & 7,2 & $1937-2009$ \\
\hline k & 227 & 4,81 & $-0,78$ & 5,98 & $-1,02$ & 6.3 & 7,1 & $1907-2009$ \\
\hline 1 & 84 & 3,77 & $-0,57$ & 5,08 & $-0,84$ & 7,1 & 7,3 & $1947-2009$ \\
\hline \multicolumn{9}{|c|}{ Papaioannou \& Papazachos Zonation } \\
\hline 35 & 314 & 4,96 & $-0,8$ & 4,617 & $-0,6735$ & 7 & 7,4 & $1902-2009$ \\
\hline 36 & 516 & 5,97 & $-1,03$ & 6,277 & $-1,0322$ & 6,7 & 7,1 & $1905-2009$ \\
\hline 37 & 335 & 5,03 & $-0,79$ & 6,0301 & $-0,9635$ & 7 & 7,4 & $1906-2009$ \\
\hline 59 & 572 & 5,16 & $-0,76$ & 5,948 & $-0,884$ & 7 & 7,4 & $1903-2009$ \\
\hline 60 & 407 & 5,02 & $-0,74$ & 6,1008 & $-0,9528$ & 7,1 & 7,5 & $1931-2009$ \\
\hline 64 & 147 & 4,37 & $-0,69$ & 6,314 & $-1,0874$ & 7,5 & 8 & $1905-2009$ \\
\hline 65 & 447 & 5,34 & $-0,82$ & 6,1224 & $-0,97729$ & 6,7 & 7,1 & $1909-2009$ \\
\hline
\end{tabular}

\section{Results and Conclusions}

Using the steps mentioned in section 4, we obtained 16 different PGA maps that are presented in figures 4 and 5 . Figure 4 is based on the new optimized zonation, while figure 5 shows the results based on the Papaioannou and Papazachos (op cited) zonation. In both figures left side presents the results obtained with the seismicity parameters defined by the maximum likelihood procedure, while the right side is based on the least squares definition of those parameters.

In figure 4, upper left part, PGA distribution was computed using the 'Margaris' attenuation relationship. Maximum values of $300 \mathrm{Gal}$ are associated with the North Sporades area and the deepest part of the North Sporades basin, of $1200 \mathrm{~m}$ depth. This is not surprising, since the uplifted Sporades islands are separated from the deepest basin depression by a nearly vertical fault that downthrows the crust by more than $5 \mathrm{~km}$ (see Makris et al., 2001; Ginzburg et al., 1986). To the east this maximum acceleration area is truncated by a NE-SW zone, running nearly parallel to the Kasandra peninsula, and displaces the PGA values to the southwest. The $300 \mathrm{Gal}$ belt is now narrower than its western branch and extends toward Limnos Island. To the north, the Thermaikos and Strymonikos gulfs are distinctly separated by the east-northeast trending Sporades and Saros rifts by striking to a northwest trend, having PGA values less than $200 \mathrm{Gal}$. 


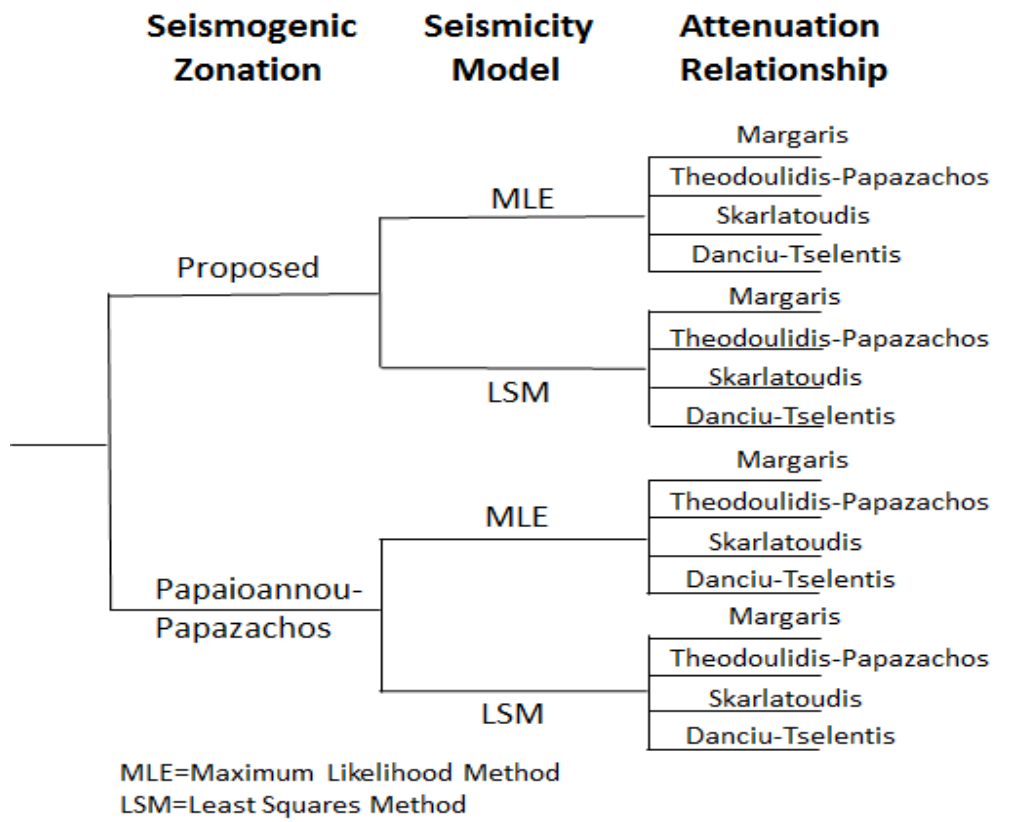

Figure 3 - Branches of the 'logic tree'.

The same trend of PGA values and their distribution is generally maintained also in the maps of figure $4 \mathrm{~b}, \mathrm{c}$ and $\mathrm{d}$ (left side) that were obtained by the 'Theodoulidis-Papazachos', 'Skarlatoudis' and 'Danciu-Tselentis' attenuation relationships, respectively. Between maps $4 \mathrm{a}$ to $4 \mathrm{~d}$, there is a $30 \%$ decrease of the peak acceleration values. We believe that the 'Margaris' attenuation relationship (4a - left side) gives the best result. It provides a more differentiated resolution of the calculated acceleration values, fits better to the seismotectonic features of the north Aegean domain, and supports the seismic hazard that this area has historically experienced (see Papazachos and Papazachou, 2003). Comparing the left with the right side of figure 4, that is the acceleration maps obtained by the least squares approximation, we observe that the hazard maps obtained by this procedure are more smoothed, correlating less accurately with the seismotectonic regime. PGA values decrease from a to $\mathrm{d}$ by 30 to $50 \%$, although the general trends are more or less consistent.

In figure 5 we calculated PGA values using the same procedure as described in figure 4; the same seismicity catalogue, attenuation relationships and seismicity parameters were used. Only the seismogenic zonation is the one published by Papaioannou and Papazachos (op cited). In figure 5a (left side) we see that maximum PGA of $300 \mathrm{Gal}$ values are shifted to the east-northeast of the Athos peninsula, and that lower values are obtained towards the Sporades islands and the southwestern part of the NAT. Moreover, the generated maps of PGA values do not represent the seismotectonic regime with sufficient accuracy and resolution. This is not surprising, since at the time these seismogenic zones were defined the available geotectonic information was inaccurate and the swath bathymetric maps did not exist. 

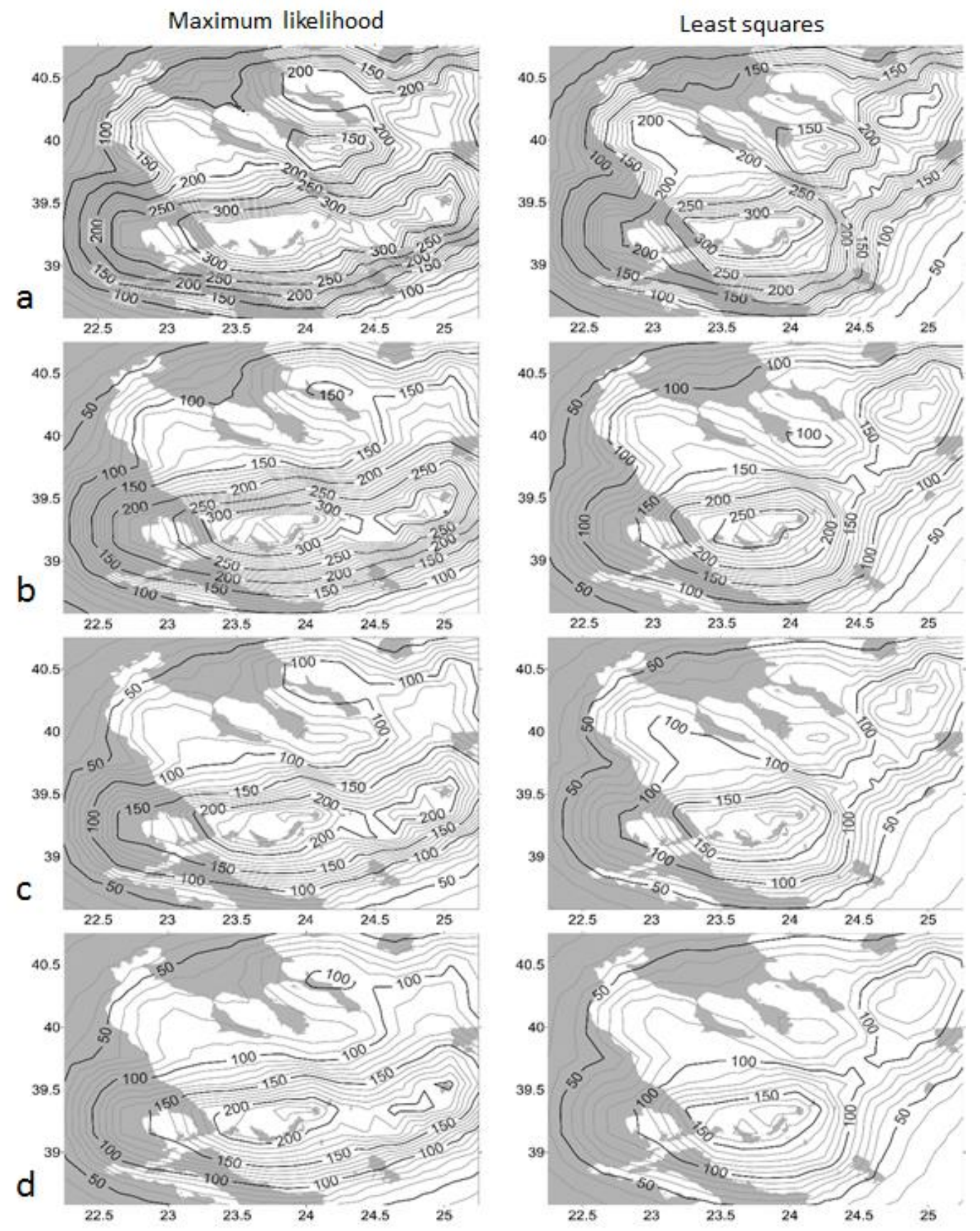

Figure 4 - PGA (in gal) with 475 year return period based on the new proposed seismogenic zonation. A to d refer to the 'Margaris', 'Theodoulidis-Papazachos', 'Skarlatoudis' and 'Danciu-Tselentis' attenuation relationships. 

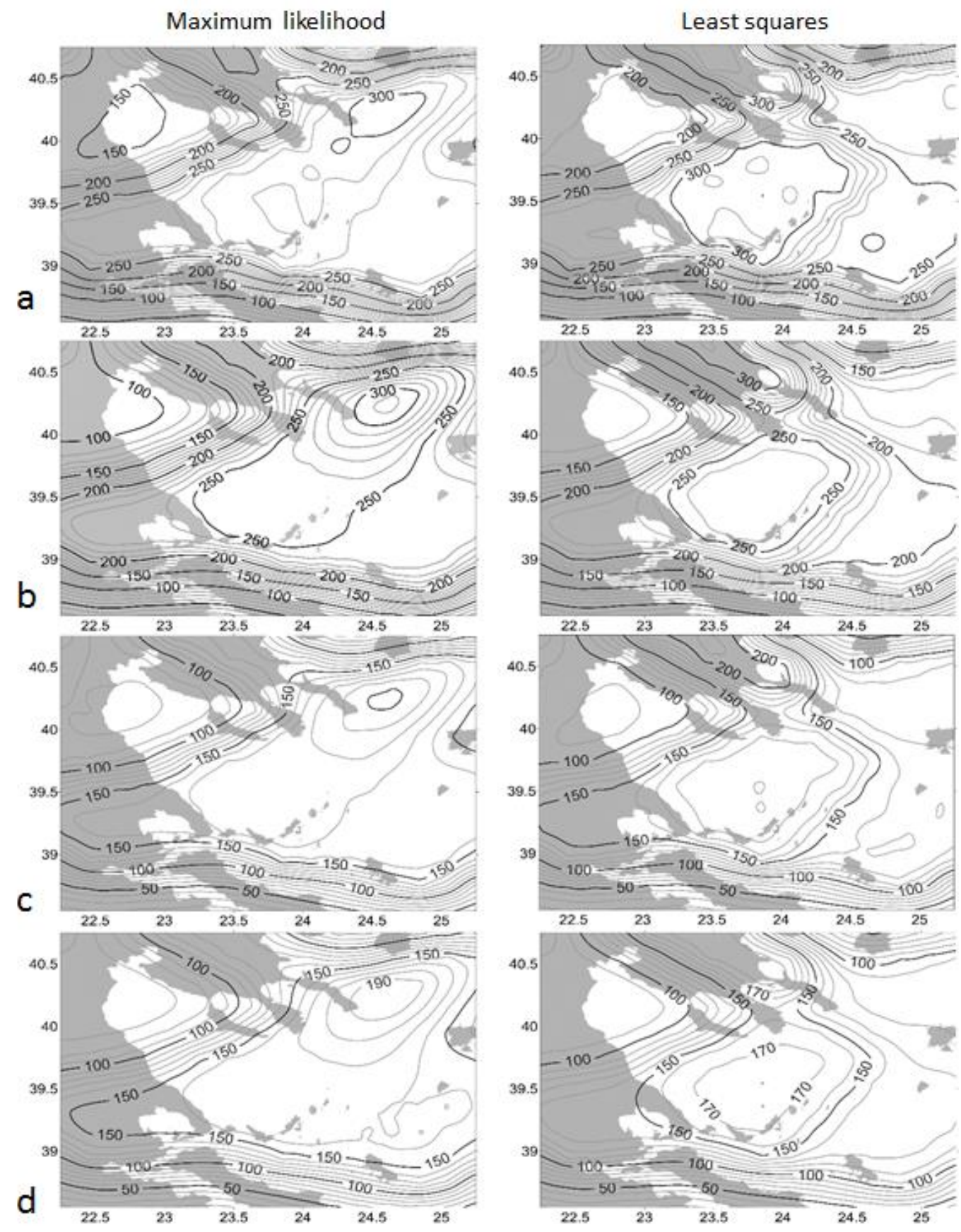

Figure 5 - PGA with 475 year return period based on the Papaioannou and Papazachos (2000) seismogenic zonation. A to d refer to the 'Margaris', 'Theodoulidis-Papazachos', 'Skarlatoudis' and 'Danciu-Tselentis' attenuation relationships.

\section{Acknowledgements}

We would like to thank an anonymous reviewer for his comments that helped us improved our original manuscript. 


\section{References}

Brooks, M. and Ferentinos, G., 1980. Structure and evolution of the Sporadhes basin of the North Aegean trough, northern Aegean Sea, Tectonophysics, 68.1, 15-30.

Coppersmith, K.J. and Youngs, R.R., 1986. Capturing uncertainty in probabilistic seismic hazard assessments within intraplate tectonic environments, Proc. of the Third US National Conference on Earthquake Engineering, 1, 301-312.

Cornell, C.A., 1968. Engineering seismic risk analysis, Bull. Seism. Soc. Am., 58, 1583-1606.

Danciu, L. and Tselendis, G.-A., 2007. Engineering ground-motion parameters attenuation relationships for Greece, Bull. Seism. Soc. Am., 97, 162-183.

Ginzburg, A., Makris, J. and Hirschleber, H., 1986. Geophysical investigations in the North Aegean Trough, Annales geophysicae. Series B. Terrestrial and planetary physics, 5(2), 167-174.

IGME, 1989. Seismotectonic Map of Greece with seismological data, 1:500.000 scale, Athens.

Kahle, H.-G., Straub, C., Reilinger, R., McGlusky, S., King, R., Hurst, K., Veis, G., Kastens, K. and Cross, P., 1998. The strain rate field in the eastern Mediterranean region, estimated by repeated GPS measurements, Tectonophysics, 294, 237-252.

Kulkarni, R.B., Youngs, R.R. and Coppersmith, K.J., 1984. Assessment of confidence intervals for results of seismic hazard analysis, Proceedings of the Eight World Conference on Earthquake Engineering, 1, 263-270.

Lalechos, N. and Savoyat, E., 1979. La sédimentation Néogène dans le fossé Nord Egéen, Proc. $6^{\text {th }}$ Coll. Geol. Aeg. Reg., Athens.

Le Pichon, X., Lybéris, N. and Alvarez, F., 1984. Subsidence history of the North Aegean trough, Geological Society, London, Special Publications, 17(1), 727-741.

Lybéris, N., 1984. Tectonic evolution of the North Aegean trough, Geological Society, London, Special Publications, 17(1), 709-725.

Makris, J., 1977. Geophysical investigations of the Hellenides. In: Hamburger Geophysikalische Einzelschriften, Reihe A, Vol. 34, University of Hamburg.

Makris, J. and Stobbe, C., 1984. Physical properties and state of the crust and upper mantle of the Eastern Mediterranean Sea deduced from geophysical data, Mar. Geol., 55, 347-363.

Makris, J., 1985. Geophysics and geodynamic implications for the evolution of the Hellenides, Geological Evolution of the Mediterranean Basin, Springer New York, 231-248.

Makris, J., Papoulia, J., Papanikolaou, D. and Stavrakakis, G., 2001: Thinned continental crust below northern Evoikos gulf, central Greece, detected from deep seismic soundings, Tectonophysics, 341, 225-236.

Makris, J., Papoulia, J. and Yegorova, T., 2013. A 3-D density model of Greece constrained by gravity and seismic data, Geophysical Journal International, 1-17.

Margaris, B., Papazachos, C., Papaioannou, C., Theodulidis, N., Kalogeras, I. and Skarlatoudis, A., 2002. Ground motion attenuation relations for shallow earthquakes in Greece. Proceedings of the XXVIII General Assembly of the European Seismological Commission (ESC).

McKenzie, D., 1972. Active tectonics of the Mediterranean region, Geophysical Journal International, 30.2, 109-185.

Ordaz, M., Aguilar, A. and Arboleda, J., 2007. CRISIS 2007 Program for computing seismic hazard. Vers. 1.1. UNAM, Mexico.

Papaioannou, Ch.A. and Papazachos, B.C., 2000. Time-independent and time-dependent seismic hazard in Greece based on seismogenic sources, Bull. Seism. Soc. Am., 90, 22-33.

Papanastassiou, D., Latoussakis, J. and Stavrakakis, G.N., 2001. A revised catalogue of earthquakes in the broader area of Greece for the period 1950-2000, Bulletin of the Geological Society of Greece 34, 1563-1566.

Papanikolaou, D., Alexandri, M. and Nomikou, P., 2006. Active faulting in the north Aegean basin, Geological Society of America Special Papers, 409, 189-209.

Papazachos, B.C. and Papazachou, C.B., 2003. The Earthquakes of Greece, Ziti Publ., Thessaloniki, 286 pp. (Greece). 
Papazachos, B.C., Comninakis P.E., Scordilis, E.M., Karakaisis, G.F. and Papazachos, C.B., 2009. A catalogue of earthquakes in the Mediterranean and surrounding area for the period 1901Sep 2009, Publ. Geophys. Laboratory, University of Thessaloniki, 1-333 pp.

Pavlides, S., Chatzipetros, A. and Valkaniotis, S., 2008. Active faults of Greece and surroundings, 33rd International Geological Congress, Oslo.

Pavlides, S. and Caputo R.; 2004. Magnitude versus faults' surface parameters: quantitative relat-i onships from the Aegean region, Tectonophysics, 380, 159-188.

Saltogianni, V., Giannou, M., Taymaz, T., Yolsal-Cevikbilen, S. and Stiros, S., 2015. Fault slip source models for the $2014 \mathrm{Mw}$ 6.9 Samothraki - Gökceada Earthquake (North Aegean Trough) combining geodetic and seismological observations, Journal of geophysical Research: Solid Earth, 120, doi:10.1 002/2015 JB0 12052.

Sboras, S., Chatzipetros, A., Pavlides, S., Fotiou, A., Pikridas, C. and Bitharis, S., 2015. The May 24, 2014 North Aegean Trough earthquake stress change and displacement patterns, $6^{\text {th }}$ Intl. INQUA meeting on Paleoseismology, Active Tectonics and Archaeoseismology, 19-24, April, Italy.

Skarlatoudis, A.A., Papazachos, C.B., Margaris, B.N., Theodulidis, N., Papaioannou, C., Kalogeras, I., Scordilis, E.M. and Karakostas, V., 2003. Empirical peak ground-motion predictive relations for shallow earthquake in Greece, Bulletin of the Seismological Society of America, 93(6), 2591-2603.

Theodulidis, N.P., and Papazachos, B.C., 1994. Dependence of strong ground motion on magnitudedistance, site geology and macroseismic intensity for shallow earthquakes in Greece II horizontal pseudo velocity, Soil Dynamics and Earthquake Engineering, 13(5), 317-343.

Tsambas, A., 2006. Model of critical earthquake in low seismic activity regions of Europe, MSc thesis, Geology Department of Aristotle University of Thessaloniki (in Greek), 47-101.

Tsambas, A., Scordilis, E.M., Papazachos, C.B. and Karakaisis, G., 2016. A homogeneous earthquake catalogue of intermediate-deep focus global seismicity: Completeness and spatio-temporal analysis, Bull. Geol. Soc. Greece, Proc. Of the $14^{\text {th }}$ Intl. Congress, Thessaloniki (in press).

Wells, D.L. and Coppersmith, K.J., 1994. New empirical relationship among magnitude, rupture length, rupture width, rupture area, and surface displacement, Bull. Seism. Soc. Am., 84, 974 1002. 